for private saving. The proposal to tax property incomes at a higher rate than other incomes is, then, apparently intended merely as an entering wedge leading eventually at best to socialism; at the worst, to Bolshevism, or anarchy. Those favoring such a program should then do so because they favor one or the other of these ends, and not because they are attempting to install a less burdensome fiscal system or to secure a more equal distribution of wealth among the people. If the last mentioned program is deemed desirable, it can be much more logically and effectively accomplished by means of progressive income taxes and by a scientific system of inheritance taxation.

As a matter of fact, the attempt to divide incomes into categories designated as "earned" and "unearned" seems to serve no practical purpose and this classification appears to have been devised, not with any intent to aid science or statecraft, but in an effort to stigmatize the institution of private property by subtly coupling with the name of the receipts derived therefrom an adjective having a derogatory implication.

Economists who carelessly use the term "unearned income" as a synonym for income arising from property are unwittingly playing into the hands of those who are thus attempting by insidious and devious methods to undermine the institution of private property. It goes without saying that scientists should avoid such a course, unless they deliberately desire to destroy this fundamental basis of the existing economic order, and, in that case, the correct policy would seem to bring the attack into the open and fight out the issue on its merits and demerits.

When economists unite in insisting upon a logical use of the term "unearned" as applied to income, it is more than probable that the term will soon be discarded as a superfluous addition to economic terminology.

\title{
Better Methods of Municipal Bonding
}

\author{
By H. W. Dodns \\ Secretary, National Municipal League
}

$\mathrm{P}^{\circ}$ OLITICAL leaders have not given sufficient thought to the advantages which would flow from the adoption of an approved uniform municipal indebtedness law by the various states. While municipal bonds as a class will perhaps never be considered as secure an investment as United States bonds, there is, in many states, room for improvement. Improvident and unsound municipal financing in one part of the country reacts upon the market for all municipals. The recent difficulties experienced by several British Columbia cities, so serious as to cause the provincial minister of finance to urge that the province assume their debts, will depress the market for all municipal bonds issued in northwestern Canada for some time to come.

If there is need for uniformity as between the various states, how much more pressing for any particular state is the matter of sound bonding practice for the cities within its borders. Large cities may develop a credit of their own, but with average cities credit is a mutual accomplishment. Only by uniformly sound practice can the municipalities (cities, counties and school districts), within a state create a market for their issues one hundred per 
cent satisfactory. Aside from the theoretical and somewhat debatable duty of the commonwealth to compel its political subdivisions to follow sound financial methods, is the practical and decisive argument of the market. Conservative bond dealers have estimated that the market for New Jersey municipal bonds was improved from twenty-five to fifty per cent by the passage of the Pierson Act of 1916.

\section{Constitutional Provisions}

Americans have never favored centralized, state administrative supervision of cities. It is considered violative of home rule. Attempts to set up such financial control over cities have usually extended to supervision of accounting methods only. Indiana recently gave a state board power to approve or disapprove proposed municipal bond issues, but the innovation, although justified at the time by good practical reasons, was so unpopular as to make an early repetition of the experiment improbable. As de Tocqueville long ago pointed out, Americans prefer to entrust necessary supervision over local government to the legislature rather than to adopt the French model of centralized administration. Our method, therefore, requires a multiplicity of laws which seek to regulate in extreme detail the actions of local government. While such legislation is often unduly meddlesome and contrary to good home rule principles, a state municipal indebtedness law, applicable alike to all local units, can not be condemned as such.

Because of the flexibility of financial practices and conditions, the regulations imposed upon municipalities should be readily amendable. Nothing, therefore, should appear in the constitution except provisions limiting the amounts of debt which local governments can incur. Practice seems to justify constitutional debt limits. The market demands them, since there appears to be no other way to estimate a city's borrowing power than as a percentage on taxable property. A city's balance sheet is meaningless as a guide in undertaking new expenditures. Since the basis for estimating proper debt contracting power is the assessed valuation of property subject to taxation, debt limits should be applied territorially to prevent evasion by the erection of special municipal districts. The debt limits should be as liberal as the market will stand and bonds which cover revenue-producing enterprises or which are issued against special assessments should be exempt from them. There are difficulties about a hard and fast limit which can be avoided by giving to a state finance commission power to review proposed bond issues after the city's debt has passed a certain percentage. Such an arrangement will protect a city from falling into loose borrowing habits, but will not render impossible wise municipal investments as is often the case under rigid constitutional debt limits.

\section{Current Expenses}

We now come to a consideration of the principal provisions embodied in a sound bond law. First of all, wise public financing requires that no loan should be contracted to meet current expenses. One exception may be made because of the common practice by which taxes are not collected until nearly the close of the fiscal year. Accordingly, temporary loans in anticipation of revenues should be permitted, but only on the condition that they be retired at an early date in the next fiscal year. It would be much more economical to advance the period of tax collections to the first part of the year and thus avoid the necessity of 
borrowing. New Jersey saves a lot of money by collecting her taxes in two installments, the first falling in the middle of the fiscal year.

In this matter of borrowing for current expenses, older municipal practice was extremely lax. Examples, such as fifty year bonds used to purchase street brooms, can be cited freely. But current expenses may mean more than operating or maintenance of existing property or administration. Particularly in the case of larger cities, many capital outlays are properly current expenses because they are recurring charges. School buildings are recurrent charges in New York. Fire equipment and street paving are recurring expenses in almost any city. Since certain sums are spent each year for paving or for new public schools, these capital outlays should be met from current funds. This policy is known as the "pay-as-you-go" policy and was first inflicted upon New York City by the legislature in 1916 at the dictation of bond dealers who had become alarmed at the city's improvidence. Of course, it was applied only to non-revenue producing improvements and its strict application has been alleviated on occasions, ostensibly because of war conditions.

As pointed out in the report of the New York joint legislative committee on taxation and retrenchment in 1920 no one would think seriously of issuing bonds to pay for office furniture, even though a steel cabinet will last indefinitely, because it represents recurring charges. Thus, any city will save thousands of dollars by estimating the amount of the bond issues which it has been accustomed to float annually for all purposes, and by providing that hereafter this amount be included in the annual tax budget. The "pay-asyou-go" policy is sound and applicable to cities of almost any size. It would be in universal practice if our officials did not find it convenient and safe to pass the burden to posterity.

\section{The Term of the Bond}

That the term of the bond should be confined to the life of the improvement is elementary. Of course the principle has been much violated in practice. In the absence of state administrative oversight, the way by which this principle is enforced (notably in the laws of Massachusetts, New Jersey and South Carolina) is to set up in the law various classes of improvements with maximum terms for each class within which the bonds must mature. This method has been criticized as too inflexible in a time when municipal engineering and construction is undergoing rapid change and improvement, but past experience demonstrates that local government authorities can not be left to themselves in this matter. Since the terms prescribed in law are maximum and not minimum periods, and since advance in technical knowledge is all in the direction of longer life for the improvement, such time limits as those under consideration are not objectionable.

Temporary financing should be permitted during the construction of an improvement for which bonds have been authorized. If it takes two or three years to complete an undertaking it is only common sense to borrow from time to time only so much money as is needed at successive periods until the work is completed and the whole bond issue can be floated. Such temporary financing likewise brings greater freedom in selling the final bond issue and enables the city to wait for a more favorable market if deemed expedient.

Sinking Funds Abolished

Now that investors have come to prefer serial bonds to sinking fund bonds 
there is no rational excuse for the latter. The report of the New York committee referred to above undertook to justify sinking funds for larger cities on the ground that they are able to employ skilful talent to administer them scientifically, and that the accumulations therein render such cities independent of market conditions in providing for their more extensive requirements. However, to most people such municipal dabbling in finance will seem many times more dangerous than the rather simple enterprises which public ownership advocates are urging upon our cities. The sinking fund principle has been tried and convicted so often as to render further comment superfluous.

Sinking funds are usually mismanaged. Efforts to provide by law automatic means for their administration independent of frail human agents fail as later years bring new market conditions. The indictment of the present New York State comptroller and his predecessor for corrupt practices in connection with state sinking funds is the latest episode in a long series of similar embarrassments. A recent study of Cleveland's sinking funds showed them to be in a deplorable state. Surprising as it may seem, a share of the blame for this must be placed upon the administration of Tom Johnson, who sometimes preferred to see the city skip its sinking fund charges rather than endanger his political program by raising the tax rate.

Serial bonds, therefore, should be compulsory, and refunding should be prohibited except in the event of extreme emergency such as war, public disaster or pestilence. Under the usual form of serials the bonds fall due in equal annual installments, which means that as successive serials are retired the annual interest charges, and thus the total debt charges, fall with each passing year. For many improvements this means only that as the property depreciates, the debt charges decrease, which is a perfectly proper relationship. However, for improvements of a non-depreciable character, or for improvements the returns from which will not begin until after an extensive period of waiting, some device which will equalize the burden, as in the case of sinking funds, may be desired.

For such cases so-called serial annuity bonds may be used. These are bonds so arranged as to make the sum of principal and interest the same for all years. As the sums paid for interest decrease, the principal redeemed increases by approximately the same amount as the interest payments drop. Of course, to work this out with absolute accuracy would necessitate some bonds issued in absurd fractions, but except in case of the smallest issues a practical approximation can be attained without indulging in bonds of odd figures and decimals.

\section{The Solution is Simple}

The solution for loose, local borrowing is easy. A state law along the lines here indicated will do the trick. State administrative oversight of local financial practices will also be an aid, and many people are prepared to recommend that a state agency be established to provide discretionary elasticity which can not be attained by mere statutory regulations. The success of the local government board in England and Canada, whose powers extend even to disapproving proposed local issues, would seem to hold out a lesson for us.

Following the report of the joint special committee on municipal finance in 1913, Massachusetts passed a bond law containing the principal provisions here set forth. All reports are that it has been an unqualified success. Its 
conditions have been followed out in practice, and the former custom by which cities and towns secured numerous unsound special concessions has been largely eliminated. New Jersey followed in 1916 with a similar law, the success of which was indicated above. South Carolina adopted a law, in 1917, following in principle the New Jersey act. The passage of such a measure represents a genuine public decision to adopt an honest borrowing policy.

\title{
Problems of a Model State Income Tax
}

\author{
By Henry Herrick Bond \\ Attorney-at-Law, Boston
}

$\mathbf{I}^{\mathrm{r}}$ $F$ we concede that the quest for uniformity in state income taxes is not too visionary to justify our labors, and turn to the practical work of drafting such a model law, we are confronted with various problems, some general and others involving legal technicalities or matters of administrative policy. It is the purpose of this article to indicate the principal underlying problems and suggest their solution.

\section{Form and Phraseology}

Let us consider first the matter of form and phraseology. Shall we adopt the language and style of the Wisconsin Act, the New York Act, or that of Massachusetts? Or shall we follow the federal drafting? The latter is obviously imperfect, carelessly worded, often ambiguous. On the other hand, Massachusetts' drafting sounds verbose to a New York resident, while New York's legislative work seems often crude and incomplete to Massachusetts ears. We must recognize, however, that the federal income tax has been applicable to an increasing percentage of the entire population since 1913, that they have become gradually acquainted with its principal requirements and the language of its paragraphs, and that any variation therefrom in future federal income tax acts is likely to be slight. Further- more, its provisions have been, and will be for years to come, the basis of judicial decisions that would only apply indirectly and questionably to an act embodying entirely different phraseology. Thus an adoption of such different language would be an economic waste of judicial effort. For these reasons, it seems preferable to adopt the federal form and language wherever possible, departing from it only where it is clearly ambiguous or where the change is so slight and so in the interests of good English that no harm can result and possibly some gain may accrue. Such an adoption of federal form and language is far more likely to be acceptable to the states as a whole than the previous efforts of a particular state legislature in this direction.

For the same reason that its provisions have become a matter of fairly general knowledge among the taxpaying public, and the basis of court decisions elucidating and defining these paragraphs, it seems advisable to adopt in the main the federal provisions defining gross income and net income. These paragraphs have been tested over a period of years, cover the subject matter adequately, and have in the main proved equitable. Most of the objections that may be urged against them arise either from faulty administration or from an interpreta- 